\title{
Characteristics of selected traits of Adult Children of Alcoholics in the context of theirparents' attitudes
}

\author{
Charakterystyka wybranych cech funkcjonowania Dorosłych Dzieci Alkoholików \\ w kontekście postaw ich rodziców
}

\section{Izabela Zakrzewska ${ }^{1}{ }_{\text {ABCDEF }}$ Agnieszka Samochowiec, ${ }^{2}$ ADE}

\author{
1Department of Psychiatry, Pomeranian Medical University in Szczecin, \\ 2Department of Clinical Psychology and Psychoprophylaxis, Institute of Psychology, \\ University of Szczecin
}

\begin{abstract}
Children growing up in families with alcohol problems experience many emotions and events that are inadequate to their age. All these experiences are related to their subsequent functioning. Having a mother or a father suffering from alcohol dependence has a big impact on who one becomes in the future and how he/she perceives the world and other people.

The purpose of this study was to determine the relationship between the level of self-esteem, satisfaction with life as well as basic hope in the so-called Adult Children of Alcoholics (ACoA), and the attitudes of their parents.

The study involved 49 persons, aged from 18 to 70 . To obtain the necessary data we used the Questionnaire Survey for Adult Children of Alcoholics, Rosenberg Self-Esteem Scale (SES), Satisfaction with Life Scale (SWLS), Basic Hope Inventory (BHI-R) and Retrospective Assessment of Parental Attitudes Questionnaire (KPR-Roc).

The results show a positive correlation between the level of self-esteem and life satisfaction, and the attitudes of autonomy and acceptance in the mothers of our subjects. Also, life satisfaction, self-esteem and basic hope proved to be interrelated, i.e. an increase within one coincided with an increase in the other two. In addition, our results show that experiencing violence in the families of persons with the ACoA syndrome significantly correlates with the retrospective assessment of their parents' attitudes. Fathers in the socalled violent families are perceived as excessively demanding, yet inconsistent, while mothers as more rejecting and less protecting.
\end{abstract}

Keywords: Adult Children of Alcoholics, hope, self-esteem, life satisfaction

\section{Streszczenie}

Dzieci dorastające $\mathrm{w}$ rodzinach $\mathrm{z}$ problemem alkoholizmu doświadczają wielu nieadekwatnych do swojego wieku emocji i zachowań. Wszystkie te doświadczenia mają związek z ich późniejszym funkcjonowaniem. Uzależnienie od alkoholu ojca lub matki wywiera duży wpływ na to kim staje się jednostka w przyszłości oraz na to jak będzie ona postrzegać świat i innych ludzi.

Celem niniejszego badania było określenie związku pomiędzy poziomem samooceny, satysfakcji z życia i nadziei podstawowej tzw. Dorosłych Dzieci Alkoholików, a postawami ich rodziców.

W badaniu udział wzięło 49 osób w wieku od 18 do 70 lat. By uzyskać niezbędne dane wykorzystano Kwestionariusz Ankiety dla Dorosłych Dzieci Alkoholików, Skalę Samooceny Rosenberga (SES), Skalę Satysfakcji z Życia (SWLS), Kwestionariusz Nadziei Podstawowej (BHI-R) oraz Kwestionariusz Retrospektywnej Oceny Postaw Rodziców (KPR-ROC).

Wyniki badań wskazują na istnienie pozytywnej korelacji pomiędzy poziomem samooceny i satysfakcji z życia, a poziomem postaw autonomii i akceptacji u matek badanych osób. Także, satysfakcja z życia, samoocena i nadzieja podstawowa są wzajemnie powiązane, tzn. wzrost jednej cechy współwystępuje ze wzrostem dwóch pozostałych. Dodatkowo wyniki badań wskazują, iż doświadczanie przemocy w rodzinie osób z syndromem DDA istotnie koreluje z retrospektywną oceną postaw rodziców. Ojcowie w tzw. przemocowych rodzinach postrzegani są jako nadmiernie wymagający, a przy tym bardziej niekonsekwentni, matki zaś jako pre zentujące postawę bardziej odrzucającą oraz mniej ochraniającą.

Słowa kluczowe: Dorosłe Dzieci Alkoholików, nadzieja, samoocena, satysfakcja z życia

\section{Introduction}

Growing up in a family with alcohol problems is a very complex process and the one that brings on consequences for many years ahead. A family understood as a system must have rules and principles through which it is able to maintain balance and harmony. If the system is affected by an alcohol problem, there are three main principles by which the family abides: "do not say," "do not feel" and "do not trust"[1]. They are the basis for the formation of numerous disturbances in shaping of the boundaries in such families. Children growing up in such systems cannot share their internal or external experiences 
with anyone outside their own family. They are forbidden from expressing their emotions and frustrations, and thus cannot trust anyone. Silence constitutes their weapon against shame, yet it is a destructive factor in relation to the problem of their loneliness [2]. Such persons develop an attitude of distrust, lack of self-confidence or confidence towards the outside world, and general confusion [3].

Lack of proper rules, and strict adherence to the rules of a dysfunctional family lead to certain imbalance. To maintain the stability of the family and to restore order and security, children, often in an unconscious way, assume certain roles. Those roles make a child establish certain behaviors in relation to other people and maintain specific patterns of behavior not only in relation to their own family, but also towards other people. We can, therefore, conclude that the role one takes, affects the development of his/her personality [4]. The most common roles include: Family Hero, Scapegoat, Lost Child, and Mascot.

Rembowski describes parental attitudes as one's feelings, ideas and behaviors associated with his/her own child [5]. They are all considered to be an important factor in shaping the personality and socio-emotional development of children [6].

Analyzing the previous typologies, Plopa pointed out that many questionnaires investigate the same dimensions. In his own questionnaire, alongside the already known dimensions: acceptance, rejection, excessive control, excessive protection and autonomy, he added inconsistency [7]. He defined acceptance as unconditional reception of the child, just as he/she is, regardless of his/her good or bad qualities. Excessively demanding attitude occurs when a parent requires total obedience from his/her child in matters concerning various aspects of life. They do not accept any form of negation of their commands, and they punish the child's disobedience with arrogance and criticism. Parents who display the attitude of autonomy provide the child with support and help in difficult situations. They let the child freely, but appropriately to his/her age, explore the world, gain new experiences and knowledge. Mood lability and nervousness are typical features of the inconsistent parental attitude. Children describe such parents as labile in expressing emotions and opinions. The attitude of acceptance intertwines with rejection and screaming, punishing with rewarding, openness with isolation. Excessive protection means that the parent wants to protect the child to the point where he/she does not allow a child to develop strategies to cope with problems and difficulties, or to formhis/her own identity. Such parents believe they need to exert constant care, even when their child is already grown up [7].
Persons growing up in a family with alcohol problems often lack a stable basis for further development in the form of support or a sense of consistency and acceptance on the part of their parents. These factors may influence their perception of the world later on in life, the level of their basic hope, self-esteem and life satisfaction.

Life satisfaction is the overall satisfaction with one's own situation in view of personal standards and values. It promotes a high level of activity and good coping in difficult situations [8]. It is shaped since childhood. Its level depends on one's resources and life experience. Resources are, among others: sex, socioeconomic status of the family, maintaining relationships with other people, or external support. Various life events can modify the level of one's life satisfaction and influence his/her perception of own resources [9]. An important determinant of life satisfaction are interpersonal contacts. They raise selfesteem, reduce negative emotions and are resource that can provide help and support in case of problems. Close and intimate contacts contribute to the greatest levels of life satisfaction [10].

Niebrzydowski recognizes self-esteem as a set of views and opinions concerning one's own abilities, physical and mental health [11]. He states that the process of self-esteem formation is long and lasts for most of a person's life. In the first one of its three stages, between the ages of 11 and 12, the so-called superficial self-esteem is formed. The second stage of the development of selfesteem is the time between 12 and 15 years of age. Selfassessment at that time includes the evaluation of one's characteristics and their noticeable effect on one's behavior and the environment. Self-esteem is mature around the age of approximately 24 years. A person of that age fully acknowledges his/her intellectual, social and emotional qualities (ibid, 1976). Although self-esteem is believed to form from roughly the age of 11 , the previous experiences of the child have a big impact on the development of his/her self-esteem in the future. It is important that self-esteem is the fundament for one's self-worth and self-efficacy [12].

Hope is shaped in early childhood, but different events occurring throughout one's entire life can modify it. According to Erikson, it is based on the conviction of two interrelated features concerning the world, namely: that it is structured and supportive, and the basis of its development is trust [13]. Another significant element of hope according to Trzebiński and Zieba [14] is justice in the world. According to their theorem, a person receives what he/she deserves from life. This means that being a good person we can expect good thingsto happen to us, while doing evil brings about punishment.

With reference to the above considerations, the objective of the study was to determine the relationship 
between selected characteristics of the functioning of Adult Children of Alcoholics and attitudes of their parents. In this paper we analyzed the relationship between life satisfaction, self-esteem and basic hope in persons with the ACoA syndrome and their retrospective assessment of their parents' attitudes, taking into account their sex and their experience of domestic violence in childhood.

\section{Material and methods}

The study was conducted at the turn of the years 2016 and 2017 at various social services centers in the Western Pomerania. Study sample comprised persons described by a specialist as suffering from the adult child of an alcoholic syndrome. Most of the subjects attended various kinds of therapy or support group meetings. Part of the group, despite the diagnosed ACoA syndrome, has never attended any therapy, or dropped out after the first meeting.

The study was individual. Respondents were personally handed questionnaires together with information on the nature of the study. All the administered tests were properly coded and completed on paper. The sets included: information on the purpose of the survey and its anonymity, Questionnaire Survey for Adult Children of Alcoholics and 4 standardized questionnaires in the following order: the Retrospective Assessment of Parental Attitudes Questionnaire(KPR-Roc), Rosenberg Self-EsteemScale (SES), Satisfaction with Life Scale (SWLS), Basic Hope Inventory (BHI-R).

The Retrospective Assessment of Parental Attitudes Questionnaire is used for conducting a retrospective assessment of parental attitudes, both the mother's and father's within the following five spheres: acceptance/rejection, excessive demands, autonomy, inconsistency and excessive protection. This tool was developed by Plopa [15]. It consists of two separate parts to evaluate the attitudes of mother and father.

The authors of the Polish adaptation and manual of Rosenberg Self-EsteemScaleare Dzwonkowska, Lachowicz-Tabaczek, Łaguna [16]. This scale is a onedimensional tool created for assessment of overall selfesteem, which is a relatively constant disposition understood as conscious attitude (negative or positive) towards the self. The tool consists of 10 items scored on a fourlevel scale.

The Satisfaction with Life Scale by Diener, Emmons, Larson, Griffin, was used in the Polish version by Juczyński [17]. The tool consists of items relating to the subject's life. The score reflects the overall sense of satisfaction with life.

The Basic Hope Inventory (BHI-R) was developed in 2009 by Trzebiński and Zieba based on Erikson's theory [18]. The scale is used to assess basic hope, understood as the conviction that the external world is structured and supportive. This conviction is a constructive factor determin- ing human response to changes and momentous events, especially in situations of irreversible losses.

The Questionnaire Survey for Adult Children of Alcoholics was developed by the author of the study. It includes questions relating to age, gender, education, place of residence, marital status. Other questions concern the diagnosis of being an adult child of an alcoholic, participating in therapy, current contacts with parents, family history of addiction, violence and possible childhood problems. The survey consists of 18 questions.

The analyses included data obtained from 49 subjects ( $55 \%$ of women and $45 \%$ of men) aged from 18 to 70 years. Both male and female groups were dominated by persons in their middle adulthood - between 31 and 50 years of age. The majority (63.3\%) of subjects attended therapy at some point in their lives. In the case of $79.6 \%$ of our subjects, alcohol dependence was present in their household since their birth. As many as $71.4 \%$ of subjects maintain contacts with at least one of the parents, although in $69.4 \%$ of families occurred various forms of violence.

\section{Results}

In order to verify our hypotheses, we applied pairwise correlation analysis and analysed the relationship between the level of self-esteem, life satisfaction and basic hope in Adult Children of Alcoholics, and the attitudes of their parents (Table 1).

In the study sample we observed the anticipated relationships between life satisfaction in Adult Children of Alcoholics and positive attitudes of their parents. Fathers' attitudes did not affect their offspring's life satisfaction levels, while mothers' acceptance was positively associated with it. Greater satisfaction with life was observed in persons whose mothers allowed free exchange of feelings and displayed spontaneous and open behavior toward the child [7]. A child who experiences such attitudeenjoys contact with their parent in adult life.

Not fully significant association also indicates the role of the autonomy provided to young people growing up in families with alcohol problems by their mothers in the formation of their life satisfaction. Therefore, we can say that mothers who understand their child's need for independence and privacy support the development of their future life satisfaction.

The same relationship existed in the self-esteem level of Adult Children of Alcoholics, while retrospective assessment of parental attitudes was not significantly associated withbasic hope in our subjects.

There are significant positive correlations of moderate strength between life satisfaction, self-esteem and basic hope. We observed the relatively weakest association between the level of self-esteem and life satisfaction, 
Table 1. Significance, strength and direction of the relationship between parental attitudes and life satisfaction, selfesteem and basic hope in adults with the ACoA syndrome

\begin{tabular}{|c|c|c|c|c|c|c|}
\hline & & \multicolumn{5}{|c|}{ Mother's attitudes } \\
\hline & & $\begin{array}{l}\text { Acceptance- } \\
\text { Rejection }\end{array}$ & $\begin{array}{l}\text { Excessive } \\
\text { demands }\end{array}$ & Autonomy & Inconsistency & $\begin{array}{l}\text { Excessive } \\
\text { protection }\end{array}$ \\
\hline \multirow{2}{*}{ Life satisfaction } & Pearson's r & $-0.078-0.119^{*}$ & & 0.268 & 0.341 & 0.065 \\
\hline & $\mathrm{P}$ & 0.016 & 0.595 & 0.063 & 0.417 & 0.656 \\
\hline \multirow{2}{*}{ Self-esteem } & Pearson's r & 0.311* & -0.103 & $0.362^{*}$ & -0.108 & 0.004 \\
\hline & $\mathrm{P}$ & 0.029 & 0.480 & 0.011 & 0.458 & 0.978 \\
\hline \multirow{2}{*}{ Basic hope } & Pearson's r & 0.189 & 0.077 & 0.180 & -0.027 & -0.012 \\
\hline & $\mathrm{P}$ & 0.193 & 0.597 & 0.216 & 0.854 & 0.932 \\
\hline & & \multicolumn{5}{|c|}{ Father's attitudes } \\
\hline & & $\begin{array}{c}\text { Acceptance- } \\
\text { Rejection }\end{array}$ & $\begin{array}{l}\text { Excessive } \\
\text { demands }\end{array}$ & Autonomy & Inconsistency & $\begin{array}{l}\text { Excessive } \\
\text { protection }\end{array}$ \\
\hline \multirow{2}{*}{ Life satisfaction } & Pearson's r & 0.153 & 0.218 & 0.065 & 0.048 & 0.230 \\
\hline & $\mathrm{P}$ & 0.295 & 0.133 & 0.655 & 0.741 & 0.112 \\
\hline \multirow{2}{*}{ Self-esteem } & Pearson's r & 0.081 & 0.004 & 0.089 & 0.032 & 0.065 \\
\hline & $\mathrm{P}$ & 0.580 & 0.980 & 0.544 & 0.825 & 0.656 \\
\hline \multirow{2}{*}{ Basic hope } & Pearson's r & 0.126 & 0.115 & 0.127 & 0.025 & 0.016 \\
\hline & $\mathrm{P}$ & 0.389 & 0.431 & 0.385 & 0.865 & 0.910 \\
\hline
\end{tabular}

${ }^{*} \mathrm{p}<0.05$

Table 2. Comparison of life satisfaction, self-esteem, basic hope and retrospective assessment of parental attitudes with regard to the occurrence of domestic violence

\begin{tabular}{|l|c|c|c|c|c|c|}
\hline & \multicolumn{2}{|c|}{ YES $\mathrm{n}=34$} & \multicolumn{2}{c|}{ NO $\mathrm{n}=15$} & \multicolumn{2}{c|}{ Mann-Whitney U test } \\
\hline & $\mathrm{M}$ & $\mathrm{SD}$ & $\mathrm{M}$ & $\mathrm{SD}$ & $\mathrm{U}$ & $\mathrm{P}$ \\
\hline Life satisfaction & 16.29 & 8.18 & 16.29 & 8.18 & 234.00 & 2.648 \\
\hline Self-esteem & 240.50 & 5.30 & 27.27 & 4.40 & & 2.00 \\
\hline Basic hope & 0,752 & & & & \\
\hline Mother's attitudes & & & & & & 0.250 \\
\hline Acceptance-Rejection & 27.44 & 11.10 & 34.53 & 7.87 & $150.00^{*}$ & $\mathbf{0 . 0 2 3}$ \\
\hline Excessive demands & 30.50 & 10.54 & 27.33 & 9.60 & 260.50 & 0.292 \\
\hline Autonomy & 30.32 & 9.19 & 32.60 & 8.93 & 227,00 & 0.543 \\
\hline Inconsistency & 29.79 & 12.37 & 25.87 & 8.40 & 208.00 & 0.307 \\
\hline Excessive protection & 26.82 & 10.16 & 33.80 & 6.38 & $153.00 *$ & $\mathbf{0 . 0 2 7}$ \\
\hline Father's attitudes & & & & & & 0.175 \\
\hline Acceptance-Rejection & 22.53 & 9.93 & 2720 & 10.78 & 192.50 & $\mathbf{0 . 0 3 6}$ \\
\hline Excessive demands & 158.50 & 10.14 & 30.87 & 10.30 & $37.06^{*}$ & 0.101 \\
\hline Autonomy & 25.12 & 9.28 & 29.40 & 8.16 & 179.50 & $\mathbf{0 . 0 2 6}$ \\
\hline Inconsistency & 37.97 & 831 & 31.53 & 9.65 & $152.50^{*}$ & 0.287 \\
\hline Excessive protection & 25.65 & 7.92 & 28.20 & 7.34 & 206.00 & \\
\hline
\end{tabular}

$\mathrm{p}<0.05$

and the strongest one between self-esteem and hope. It is worth noting that these associations are of correlational nature, meaning that higher intensities of the selected variables coexist alongside each other, but the applied methodology does not allow to draw conclusions concerning the causality of the observed dependence.

In the study we hypothesised that men and women may differ regarding the levels of the selected variables. Since the subgroups were similar in numbers and the result distributions were similar to normal, we applied parametric Student t-test for two independent groups. Due to high significance of differences, we may conclude that gender does not differentiate men and women in this regard.

Additionally, we examined the relationship between domestic violence, the level of the investigated variables and retrospective assessment of parental attitudes. Due to the large differences in sample sizes of the subjects who experienced domestic violence and those who did not, we applied a nonparametric Mann-Whitney U Test (Table 2).

As many as $69 \%$ of the subjects said they have experienced symptoms of domestic violence, but this fact did not affect their level of life satisfaction, self-esteem or basic hope. However, they rated their mothers lower on the scale of acceptance-rejection and protection. Lower levels of the selected variables were observed in subjects whose mothers have treated them with reserve and have failed to build close, accepting relationships. Fathers of our subjects with experience of domestic violence in childhood were perceived as overly demanding andmore inconsistent in their behavior. They demanded absolute obedience, used various prohibitions and forms of punishment, not taking into account their children's abilities or desires. In addition, they were nervous 
and erratic, making it difficult to build positive relationships with their children.

\section{Discussion}

Many studies indicate that appropriate parental attitudes create proper conditions for the intellectual, emotional and psychosocial development of the child [19]. Mother's positive attitudes in relation to her child may strengthen his/her self-esteem, and thus contribute to greater satisfaction with his/her current situation.

The level of basic hope is affected by critical events occurring throughout one's entire life. In our subjects it could, therefore, be significantly modified by events taking place after they have reached maturity, i.e. in the postchildhood period.

Interestingly, the attitudes of the fathers were not related to any of the analyzed variables. This may be due to the fact that the fathers of our subjects were mostly addicted to alcohol and may have had poorer contact with their offspring or have not participated in their upbringing at all. The mothers could also protect their children from contact with the addicted parent or even isolate their spouse from the family.

Many to datestudies report on a link between selfesteem and life satisfaction [20]. There are also findings quoting a positive correlation between basic hope and the level of self-esteem. All the three variables let one adapt to the changing conditions of life, and at the same time, maintain an appropriate course of personality development. The conviction of the meaningfulness of the surrounding world and life events is linked to self-esteem. Hope shows a positive correlation with the level of life satisfaction and positive mood [21]. Persons with high self-esteemadapt to new situations more easily andperceive the world around them in a more positive way. They believe that what they experience in life is structured and manageable, and the environment they live in is safe and favourable. Higher self-esteem, therefore, results in an increase in the level of basic hope and overall satisfaction with life. Similarly, the consequence of having low selfesteem is a belief in the hostility of the world, injustice and lack of predictability. Such persons do not believe in themselves, do not take challenges and adapt to new situations in a less effective way. Their level of basic hope and life satisfaction decreases.

Growing up in a family afflicted with alcohol problem can be a traumatizing experience for a child. In such family systems, common problems include disturbed relationships, lack of rules or proper boundaries. Violence thus becomes just another perturbation in one's life. Persons with no support from their parents may recognize violence as a manifestation of a parent's resentment and rejection or, on the contrary, may feel needed as an object of emotional discharge. An important factor here may be the role that the child assumes in the family.

In our study, most of the subjects pointed to the fathers as the perpetrators of violence. Inconsistency and excessive requirements towards their children could contribute to their use of violence. Mothers, often victims themselves, are perceived by their children as not very resourceful and unable to stand up to the perpetrator.

It is worth noting that the structure and functioning of families with an alcohol problem are usually very complex, heterogeneous and inefficient. The mechanisms and rules that govern such systems are slightly different than those observed in healthy families. They can, therefore, affect the development of children in a different way. Adult Children of Alcoholics vary in terms of the roles they assumed in childhood, which conditioned their behavior and responsibilities.

It is important to note that different persons can react differently to their close ones' alcohol dependence. Unfortunately, they often experience negative events in their lives [22]. Adult Children of Alcoholics tend to manifest lower resilience, lower self-esteem and have less social support in comparison with the control group. Both social support and the level of self-esteem are related to the resilience level of the ACoA. It is important to develop programs which help to increase the level of self-esteem in these patients [23].

Adult Children of Alcoholics are reluctant to discuss their childhood memories and show fairly large resistance to talk about their parents. They typically experience certain degree of social pressure and want to avoid stigmatization. Such situations may hinder their ability to solve everyday life problems [24].

During adolescence and adulthood our subjects could draw from many resources which were not covered in the study, such as support from their extended family, friends and school/work environment, their current situation, or psychotherapy not associated with being an adult child of an alcoholic [25].

\section{Conclusions}

The conclusions of our study reflect on the role of parental attitudes in shaping basic hope, self-esteem and life satisfaction in children whose one or both parents/guardians are addicted to alcohol. It seems to be important, not only in families with addiction problems, for parents to shape positive attitudes towards their children that may strengthen the resources of the entire family and allow all its members to develop their full potential.

It is vitalto search for factors that can protect children from the impact of their parents' negative attitudes. Therefore,it appears that psychological work with the parents in the area of psychoeducation, stress-coping 
strategies, emotions and shaping their parenting skills, influencing the formation of certain attitudes in their offspring, would prove beneficial. In the future studies on the subject it would be worth remembering that self-esteem, satisfaction with life and basic hope can be shaped and undergo changes throughout a person's entire life. It would be useful to carry out long-term research and focus on a comparison of subjects before and after the therapy. Due to the breadth and multidimensionality of the problem of growing up in a family with alcohol problems, it would be worthwhile to apply qualitative methods, e.g. in-depth interviews alongside the quantitative ones (surveys and questionnaires).

\section{Wstęp}

Dorastanie $\mathrm{w}$ rodzinie $\mathrm{z}$ problemem alkoholowym jest procesem bardzo złożonym i mającym konsekwencje przez wiele następnych lat. Rodzina rozumiana jako pewien system musi posiadać reguły i zasady, dzięki którym jest w stanie zachować równowagę i harmonię funkcjonowania. W systemie dotkniętym przez problem alkoholowy istnieją trzy główne zasady kształtujące życie rodzinne: „nie mów”, „nie czuj”, nie ufaj” [1]. Są one podstawą do powstania licznych nieprawidłowości w kształtowaniu się granic w takich rodzinach. Dzieci wychowujące się w tych systemach nie mogą dzielić się swoimi przeżyciami wewnętrznymi i zewnętrznymi z nikim z poza własnej rodziny. Mają zakaz wyrażania swoich emocji i frustracji, a co za tym idzie nie mogą nikomu zaufać. Milczenie broni ich przed poczuciem wstydu, jest jednak czynnikiem destrukcyjnym w stosunku do osamotnionych w problemie osób [2]. W takich osobach wykształca się postawa braku ufności, pewności co do siebie i świata i ogólnego zdezorientowania [3].

Brak prawidłowych reguł i sztywne trzymanie się dysfunkcyjnych zasad doprowadzają rodzinę do zachwiania jej równowagi. Aby utrzymać stabilność rodziny, przywrócić porządek i bezpieczeństwo, dzieci często w sposób nieuświadomiony przyjmują pewne role. Przybierając pewną kreację dziecko kształtuje określone zachowania w stosunku do innych osób oraz trzyma się określonych wzorców zachowań nie tylko w kontakcie $\mathrm{z}$ rodziną, ale także $\mathrm{z}$ innymi ludźmi. Można więc stwierdzić, iż rola jaką przyjmuje dana osoba wpływa na kształtowanie się osobowości jednostki [4]. Najczęściej przyjmowanymi rolami są: Bohater Rodzinny, Kozioł Ofiarny, Zagubione Dziecko oraz Maskotka.

Rembowski mówi, iż postawy rodzicielskie są to uczucia związane $\mathrm{z}$ dzieckiem, myślenie o nim i zachowania wobec niego [5]. Przyjmuje się je za istotny czynnik kształtowania osobowości i rozwoju społeczno-emocjonalnego dzieci [6].

Analizując uprzednio stworzone przez innych autorów typologie, Plopa zwrócił uwagę na fakt, iż wiele wymiarów jest powielanych $w$ kolejnych kwestionariuszach. W swoim kwestionariuszu, do znanych już przedtem wymiarów: akceptacji, odrzucenia, nadmiernej kontroli, nadmiernego ochraniania i autonomii dołożył skalę niekonsekwencji [7]. I tak zdefiniował on akceptację jako bezwarunkowe przyjmowanie dziecka, takim jakie ono jest, bez względu na jego dobre czy złe cechy. Postawa nadmiernie wymagająca występuje $\mathrm{w}$ momencie, gdy rodzic wymaga od swojego dziecka bezkrytycznego posłuszeństwa $\mathrm{w}$ sprawach dotyczących wielu płaszczyzn życia. Nie zgadza się on na negacje jego poleceń, a nieposłuszność, kara arogancją i krytyką. Rodzic stosujący postawę autonomii był dla dziecka wsparciem i pomocą w trudnych sytuacjach. Pozwalał mu na swobodne, lecz zgodne z wiekiem, eksplorowanie świata, zdobywanie nowych doświadczeń oraz zawieranie kolejnych znajomości. Chwiejność nastroju i nerwowość charakteryzują postawę niekonsekwentną rodzica. Dzieci wspominają takich rodziców, jako osoby labilne w wyrażaniu emocji oraz opinii. Postawa akceptująca splatała się w nich $\mathrm{z}$ odrzuceniem i krzykiem, karanie $\mathrm{z}$ nagradzaniem, otwartość z izolacją. Nadmierne ochranianie charakteryzuje się tym, że rodzic chce zabezpieczyć całe życie dziecka, nie pozwala mu na rozwój strategii radzenia sobie z problemami i trudnościami, ani na rozwój jego tożsamości. Posiada on przekonanie o ciągłej potrzebie opieki nad dzieckiem, nawet w momencie gdy jest ono już dorosłe [7].

Osoby wychowujące się $\mathrm{w}$ rodzinie z problemem alkoholowym często nie mają stabilnego podłoża do dalszego rozwoju w postaci wsparcia ze strony rodziny czy poczucia konsekwencji i akceptacji ze strony rodziców. Czynniki te mogą wpływać na ich postrzeganie świata w późniejszym życiu, poziom ich nadziei podstawowej, samooceny czy satysfakcji z życia.

Satysfakcja z życia jest to ogólna ocena zadowolenia jednostki ze swojej sytuacji życiowej odnoszona do osobistych standardów i wartości. Wysoki jej poziom sprzyja aktywności i dobremu radzeniu sobie w trudnych sytuacjach życiowych [8]. Kształtuje się ona już od dzieciństwa. Jej poziom zależy od zasobów osoby oraz zdarzeń jakich doświadczyła ona wswoim dotychczasowym życiu. Zasobami mogą być np. płeć, status socjoekonomiczny rodziny, utrzymywanie relacji z innymi ludźmi, wsparcie z zewnątrz. Sytuacje życiowe mogą modyfikować poziom satysfakcji z życia i wpływać na postrzeganie przez jednostkę swoich zasobów [9]. Ważną determinantą satysfakcji z życia są kontakty interpersonalne. Podnoszą one samoocenę, ograniczają negatywne emocje oraz są zasobem, który zapewnia nam otrzymanie pomocy i wsparcia w razie problemów. Najlepsze z punktu widzenia satysfakcji z życia są kontakty bliskie i intymne [10].

Niebrzydowski ujmuje samoocenę jako zespół sądów i opinii na temat swoich możliwości oraz cech fizycznych i psychicznych [11]. Stwierdza on iż proces tworzenia się samooceny jest długotrwały i trwa przez większość 
życia. W pierwszym z trzech etapów, pomiędzy 11, a 12 rokiem życia kształtuje się tzw. samoocena powierzchowna. Drugim etapem rozwoju samooceny jest czas pomiędzy 12 , a 15 rokiem życia. Ówczesna pogłębiona samoocena zawiera w sobie wartościowanie swoich cech oraz zauważalny wpływ ich na zachowanie oraz otoczenie osoby. Samoocena dojrzała kształtuje się po 24 roku życia. Człowiek samodzielnie odnosi się wtedy do swoich możliwości intelektualnych, społecznych i emocjonalnych (tamże, 1976). Mimo, iż świadomie samoocena kształtuje się od mniej więcej 11 roku życia dziecka wcześniejsze doświadczenia mają duży wpływ na kierunek rozwoju samooceny w przyszłości. Ważnym jest, iż „samoocena leży u podstaw poczu cia wartości i własnej skuteczności” [12].

Nadzieja jest kształtowana już we wczesnym dzieciństwie, jednak wydarzenia w ciągu całego życia mogą ją modyfikować. Według Eriksona jest ona przeświadczeniem o dwóch powiązanych ze sobą cechach świata: że jest on uporządkowany i przychylny ludziom, a podstawą jego rozwoju jest zaufanie [13]. Dodatkowym elementem wprowadzonym do składowych nadziei podstawowej przez Trzebińskiego i Ziębę [14] jest sprawiedliwość świata. Twierdzenie to mówi o tym, iż człowiek otrzymuje od życia to na co zasłużył. Oznacza to, iż będąc dobrym możemy oczekiwać w życiu przychylności, czyniąc zło natomiast kary.

W nawiązaniu do powyższych rozważań za cel badania postawiono określenie związku pomiędzy wybranymi charakterystykami funkcjonowania dorosłych dzieci alkoholików a postawami ich rodziców. W niniejszej pracy przeanalizowano związek pomiędzy poziomem satysfakcji z życia,samooceny oraz nadziei podstawowej osób z syndromem DDA w kontekście retrospektywnej oceny postaw ich rodziców, uwzględniając również płeć badanych oraz doświadczenie przez nich przemocy w dzieciństwie.

\section{Materiał i metoda}

Badanie zostało przeprowadzone na przełomie 2016/2017 na terenie ośrodków pomocy w województwie zachodniopomorskim. Do udziału zostały zaproszone osoby, opisane przez specjalistę, jako posiadające syndrom Dorosłego Dziecka Alkoholika. Większość z tych osób uczestniczyło w różnego rodzaju grupach wsparcia czy terapiach.Część grupy pomimo zdiagnozowania bycia osobą z syndromem DDA nie poddała się nigdy terapii, bądź zakończyła ją po pierwszym spotkaniu.

Badania miały charakter indywidualny. Respondenci otrzymywali do rąk własnych kwestionariusze wraz z informacją o charakterze badania. Testy były odpowiednio kodowane i wypełniane w wersji papierowej, na którą składały się: informacje o celu badania i jego anonimowości, Kwestionariusz Ankiety dla Dorosłych Dzieci Alkoholików, 4 standaryzowane kwestionariusze wypełniane w kolejności: Kwestionariusz Retrospektywnej Oceny Postaw Rodziców (KPRROC), Skala Samooceny Rosenberga (SES), Skala Satysfakcji z Życia (SWLS), Kwestionariusz Nadziei Podstawowej (BHI-R).
Zastosowane narzędzia spełniają kryteria trafności i rzetelności psychometrycznej.

Kwestionariusz Retrospektywnej Oceny Postaw Rodziców służy do retrospektywnej oceny postaw rodzicielskich zarówno matki i ojca w zakresie pięciu postaw rodzicielskich: akceptacji/odrzucania, wymagania, autonomii, niekonsekwencji i ochraniania. Narzędzie to zostało opracowane przez Plopę[15]. Składa się ono z dwóch osobnych części: do oceny postaw matki i ojca.

Autorami polskiej adaptacji Skali Samooceny Rosenberga oraz podręcznika są Dzwonkowska, LachowiczTabaczek, Łaguna[16]. Skala ta jest narzędziem jednowymiarowym, które pozwala na ocenę poziomu ogólnej samooceny, która jest względnie stałą dyspozycją, rozumianą jako świadoma postawa wobec Ja (negatywna bądź pozytywna). Narzędzie składa się z 10 stwierdzeń diagnostycznych, do których badany ustosunkowuje się na czterostopniowej skali.

Zastosowana Skala Satysfakcji z Życia autorstwaDiener, Emmons, Larson, Griffin, w polskiej wersji Juczyńskiego[17]. Narzędzie składa się z twierdzeń odnoszących się dotychczasowego życia osoby badanej, do których ma się ustosunkować. Wynikiem pomiaru jest ogólny wskaźnik poczucia zadowolenia z życia.

Kwestionariusz Nadziei Podstawowej (BHI-R) został skonstruowany w 2009 roku przez Trzebińskiego i Ziębę na podstawie teorii Eriksona [18]. Skala służy do oceny nadziei podstawowej, rozumianej jako przeświadczenie jednostki o uporządkowaniu i sensowności świata oraz jego przychylności ludziom. Przeświadczenie to stanowi czynnik warunkujący konstruktywne reagowanie człowieka na zmiany i przełomowe wydarzenia, zwłaszcza na sytuacje ponoszenia nieodwracalnych strat.

Kwestionariusz Ankiety dla Dorosłych Dzieci Alkoholików został skonstruowany przez autora badania samodzielnie. Zawiera pytania odnoszące się do: wieku, płci, wykształcenia, miejsca zamieszkania, stanu cywilnego. Dodatkowo zawarte zostały w nim pytania o diagnozę dotyczącą bycia dorosłym dzieckiem alkoholika, o uczestniczeniu w terapii, o aktualnych kontaktach z rodzicami, o historii uzależnień w rodzinie, o ewentualnej przemocy oraz szczególnej sytuacji z dzieciństwa. Ankieta składa się z 18 pytań.

W analizach uwzględniono dane uzyskane od 49 osób (w tym 55\% kobiet i 45\% mężczyzn) w wieku od 18 do 70 lat. Zarówno wśród kobiet jak i mężczyzn dominowały osoby w okresie średniej dorosłości - pomiędzy 31. a 50. rokiem życia. Większość $(63,3 \%)$ badanych uczestniczyło w swoim życiu w terapii. U 79,6\% badanych uzależnienie od alkoholu było obecne w domu już od ich urodzenia. Aż 71,4\% z badanych osób utrzymuje kontakty z minimum jednym z rodziców, mimo iż w 69,4\% rodzin dochodziło do różnych przejawów przemocy.

\section{Wyniki}

W celu weryfikacji postawionych hipotez zastosowano analizękorelacji parami oraz przeanalizowano związek pomiędzy poziomem samooceny, satysfakcji z życia i nadziei podstawowej Dorosłych Dzieci Alkoholików, a postawami ich rodziców (Tabela 1). 
Tabela 1. Weryfikacja istotności, siły i kierunku związków pomiędzy postawami rodziców a poziomem satysfakcji z życia, samooceny i nadziei podstawowej dorosłych osób z zespołem DDA

\begin{tabular}{|c|c|c|c|c|c|c|}
\hline & & \multicolumn{5}{|c|}{ Postawy matki } \\
\hline & & $\begin{array}{l}\text { Akceptacja- } \\
\text { Odrzucenie }\end{array}$ & $\begin{array}{l}\text { Nadmierne } \\
\text { wymagania }\end{array}$ & Autonomia & $\begin{array}{l}\text { Niekonse- } \\
\text { kwencja }\end{array}$ & $\begin{array}{c}\text { Nadmierna } \\
\text { ochrona }\end{array}$ \\
\hline \multirow{2}{*}{$\begin{array}{l}\text { Satysfakcja } \\
\text { z życia }\end{array}$} & rPearsona & $0,341^{*}$ & $-0,078$ & 0,268 & $-0,119$ & 0,065 \\
\hline & $\mathrm{P}$ & 0,016 & 0,595 & 0,063 & 0,417 & 0,656 \\
\hline \multirow{2}{*}{ Samoocena } & rPearsona & $0,311^{*}$ & $-0,103$ & $0,362^{*}$ & $-0,108$ & 0,004 \\
\hline & $\mathrm{P}$ & 0,029 & 0,480 & 0,011 & 0,458 & 0,978 \\
\hline \multirow{2}{*}{$\begin{array}{l}\text { Nadzieja pod- } \\
\text { stawowa }\end{array}$} & rPearsona & 0,189 & 0,077 & 0,180 & $-0,027$ & $-0,012$ \\
\hline & $\mathrm{P}$ & 0,193 & 0,597 & 0,216 & 0,854 & 0,932 \\
\hline & & \multicolumn{5}{|c|}{ Postawy ojca } \\
\hline & & $\begin{array}{l}\text { Akceptacja- } \\
\text { Odrzucenie }\end{array}$ & $\begin{array}{l}\text { Nadmierne } \\
\text { wymagania }\end{array}$ & Autonomia & $\begin{array}{c}\text { Niekonse- } \\
\text { kwencja }\end{array}$ & $\begin{array}{c}\text { Nadmierna } \\
\text { ochrona }\end{array}$ \\
\hline \multirow{2}{*}{$\begin{array}{l}\text { Satysfakcja } \\
\text { z życia }\end{array}$} & rPearsona & 0,153 & 0,218 & 0,065 & 0,048 & 0,230 \\
\hline & $\mathrm{P}$ & 0,295 & 0,133 & 0,655 & 0,741 & 0,112 \\
\hline \multirow{2}{*}{ Samoocena } & rPearsona & 0,081 & 0,004 & 0,089 & 0,032 & 0,065 \\
\hline & $\mathrm{P}$ & 0,580 & 0,980 & 0,544 & 0,825 & 0,656 \\
\hline \multirow{2}{*}{$\begin{array}{l}\text { Nadzieja pod- } \\
\text { stawowa }\end{array}$} & rPearsona & 0,126 & 0,115 & 0,127 & 0,025 & 0,016 \\
\hline & $\mathrm{P}$ & 0,389 & 0,431 & 0,385 & 0,865 & 0,910 \\
\hline
\end{tabular}

${ }^{*} \mathrm{p}<0.05$

Tabela 2. Porównanie poziomu satysfakcji z życia, samooceny i nadziei podstawowej oraz retrospektywnej oceny postaw rodziców z uwzględnieniem występowania przemocy w rodzinie

\begin{tabular}{|c|c|c|c|c|c|c|}
\hline & \multicolumn{2}{|c|}{ TAK, $\mathrm{n}=34$} & \multicolumn{2}{|c|}{ NIE, $n=15$} & \multicolumn{2}{|c|}{ Test U Manna-Whiteneya } \\
\hline & $\mathrm{M}$ & SD & $\mathrm{M}$ & SD & $\mathrm{U}$ & $\mathrm{P}$ \\
\hline Satysfakcja z życia & 16,29 & 8,18 & 16,29 & 8,18 & 234,00 & 0,648 \\
\hline Samoocena & 27,00 & 5,30 & 27,27 & 4,40 & 240,50 & 0.752 \\
\hline Nadzieja podstawowa & 56,65 & 10,52 & 53,93 & 7,70 & 202,00 & 0,250 \\
\hline \multicolumn{7}{|l|}{ Postawy matki } \\
\hline Akceptacja-odrzucenie & 27,44 & 11,10 & 34,53 & 7,87 & $150,00^{*}$ & 0,023 \\
\hline Nadmierne wymagania & 30,50 & 10,54 & 27,33 & 9,60 & 260,50 & 0,292 \\
\hline Autonomia & 30,32 & 9,19 & 32,60 & 8,93 & 227,00 & 0,543 \\
\hline Niekonsekwencja & 29,79 & 12,37 & 25,87 & 8,40 & 208,00 & 0,307 \\
\hline Nadmierna ochrona & 26,82 & 10,16 & 33,80 & 6,38 & $153,00^{*}$ & 0,027 \\
\hline \multicolumn{7}{|l|}{ Postawy ojca } \\
\hline Akceptacja-odrzucenie & 22,53 & 9,93 & 27,20 & 10,78 & 192,50 & 0,175 \\
\hline Nadmierne wymagania & 37,06 & 10,14 & 30,87 & 10,30 & $158,50 *$ & 0,036 \\
\hline Autonomia & 25,12 & 9,28 & 29,40 & 8,16 & 179,50 & 0,101 \\
\hline Niekonsekwencja & 37,97 & 8,31 & 31,53 & 9,65 & $152,50 *$ & 0,026 \\
\hline Nadmierna ochrona & 25,65 & 7,92 & 28,20 & 7,34 & 206,00 & 0,287 \\
\hline
\end{tabular}
${ }^{*} \mathrm{p}<0.05$

W badanej grupie zaobserwowano zakładane związki pomiędzy satysfakcją z życia Dorosłych Dzieci Alkoholików, a pozytywnymi postawami ich rodziców. Postawy ojca nie wchodziły w żadne związki z poczuciem satysfakcji z życia potomstwa, natomiast wśród postaw matek postawa akceptacji była korzystnie z nim powiązana. Większą satysfakcją z życia charakteryzowały się więc osoby, których matki pozwalały na swobodną wymianę uczuć oraz spontaniczne i otwarte zachowania wobec dziecka [7]. Dziecko obdarzone taką postawą w dorosłym życiu odczuwa przyjemność z kontaktu ze swym rodzicem.

Nie w pełni istotny związek wskazuje również na rolę autonomii okazywanej przez matkę w kształtowaniu się życiowej satysfakcji u młodych osób wychowujących się w rodzinach z problemem alkoholowym. Można więc powiedzieć, że matki rozumiejące potrzebę samodzielności i prywatności dziecka wspierają rozwój jego przyszłej satysfakcji z życia.

Takie same związki zachodzą w przypadku poziomu samooceny Dorosłych Dzieci Alkoholików, natomiast wśród badanych retrospekcyjna ocena postaw rodziców nie była w istotny sposób powiązana z poczuciem nadziei podstawowej.

Pomiędzy poziomem satysfakcji z życia, samooceny i nadziei podstawowej zachodzą istotne korelację o dodatnich kierunkach i umiarkowanych siłach. Relatywnie najsłabszy związek łączy poziom samooceny z satysfakcją z życia, zaś najmocniejszy - samoocenę i nadzieję. Warto podkreślić, że związki te mają charakter korelacyjny, co oznacza iż wyższe natężenia wybranych zmiennych współwystępują ze sobą, ale metodyka przeprowadzonego badania nie pozwala wnioskować, która ze zmiennych jest przyczyną, a które skutkami obserwowanych zależności. 
W badaniu założono hipotezę, iż kobiety i mężczyźni mogą różnić się od siebie poziomem wybranych zmiennych. Ponieważ podgrupy wydzielone ze względu na płeć posiadały podobną liczebność, a rozkłady wyników były zbliżone do normalnego, zastosowano parametryczny test t-Studenta dla dwóch grup niezależnych. Ze względu na wysokie wartości wskaźników istotności różnic uznać należy, iż płeć nie różnicuje badanych kobiet i mężczyzn pod tym kątem.

Dodatkowo zbadany został związek pomiędzy występowaniem przemocy $\mathrm{w}$ rodzinie, a poziomem powyższych zmiennych oraz retrospektywną oceną postaw rodziców. Ze względu na dużą różnice w liczebności badanych doświadczających przemocy i jej nie doświadczających, do sprawdzenia tej hipotezy wykorzystano nieparametryczny Test U Manna-Whiteneya (Tabela 2).

Aż 69\% badanych przyznało, że doświadczało przejawów przemocy w rodzinie, ale fakt ten nie miał związku z poziomem ich satysfakcji z życia, samooceny ani nadziei podstawowej. Badani oceniali jednak swoje matki niżej na skali akceptacji-odrzucenia oraz ochrony. Niższy poziom wybranych zmiennych uzyskały osoby, których matki traktowały z dystansem oraz nie budowały z nimi bliskiej, akceptującej relacji. Ojcowie badanych z doświadczeniem w dzieciństwie przemocy domowej postrzegani byli jako nadmiernie wymagający, a przy tym bardziej niekonsekwentni w swoim zachowaniu. Wymagali oni bezwzględnego posłuszeństwa, stosowali wiele zakazów i kar, nie licząc się z możliwościami i pragnieniami swoich dzieci. Dodatkowo byli zmienni i nerwowi, co utrudniało budowanie pozytywnych relacji z dziećmi.

\section{Dyskusja}

Wiele badań wskazuję na to iż, prawidłowe postawy prezentowane przez rodziców stwarzają należyte warunki do intelektualnego, uczuciowego i psychospołecznego rozwoju dziecka [19]. Pozytywne postawy prezentowane względem dziecka przez matkę mogą wzmacniać jego poczucie własnej wartości, a co za tym idzie kształtować większe zadowolenie z sytuacji w jakiej się aktualnie znajduje.

$\mathrm{Na}$ poziom nadziei podstawowej wpływać mogą przełomowe wydarzenia $\mathrm{z}$ całego życia jednostki. Jej poziom mógł zostać zatem znacząco zmodyfikowany przez zdarzenia, które miały miejsce już po zakończeniu okresu dzieciństwa osób badanych.

Co ciekawe, postawy ojców nie były powiązane $\mathrm{z}$ żadną z analizowanych zmiennych. Może być to związane $\mathrm{z}$ tym, iż w grupie badawczej przeważali ojcowie uzależnieni od alkoholu, którzy mogli mieć gorszy kontakt ze swoim potomstwem bądź nie uczestniczyć w ich wychowaniu. Matki mogły także ochraniać swoje dzieci przed kontaktami z uzależnionym rodzicem bądź wręcz izolować małżonka od rodziny.
W wielu dotychczasowych badaniach stwierdzony został związek samooceny z satysfakcją z życia[20].Także nadzieja podstawowa, wykazała pozytywną korelację $\mathrm{z}$ poziomem samooceny we wcześniejszych badaniach. Wszystkie trzy zmienne pozwalają jednostce pozytywnie adaptować się do zmieniających się warunków życia, przy zachowaniu korzystnego toru rozwoju osobowości. Przeświadczenie o sensowności świata i wydarzeń otaczających jednostkę jest powiązane z poczuciem własnej wartości. Nadzieja wykazuje dodatnie korelacje z poziomem satysfakcji z życia i pozytywnym nastrojem[21]. Osoby posiadające wysoką samoocenę łatwiej adaptują się do nowych sytuacji oraz pozytywniej oceniają otaczający je świat. Wierzą, że to co je spotyka jest uporządkowane i zależne od nich samych, a środowisko w jakim żyją jest bezpieczne i przychylne nim samym. Wzrost samooceny skutkuje zatem podwyższeniem się poziomu nadziei podstawowej oraz ogólnej satysfakcji z życia. Analogicznie wynikiem posiadania niskiej samooceny jest przeświadczenie o wrogości świata, niesprawiedliwości oraz braku przewidywalności. Osoba taka nie wierzy w siebie, nie podejmuje wyzwań oraz gorzej adaptuje się do nowych sytuacji. Jej poziom nadziei podstawowej oraz satysfakcji $\mathrm{z}$ życia maleje.

Wychowywanie się $\mathrm{w}$ rodzinie $\mathrm{w}$ problemem alkoholowym może być dla dziecka traumatyzującym przeżyciem. W tego typu systemach rodzinnych powszechnymi problemami są m.in. zaburzone relacje, brak reguł i prawidłowo postawionych granic. Przemoc staje się więc tylko kolejnym zaburzeniem w życiu jednostki. Osoba nie mająca wsparcia $\mathrm{w}$ rodzicach może uznawać, że akty przemocy są przejawem niechęci i odrzucenia ze strony rodzica bądź wręcz odwrotnie czuć się potrzebna rodzicowi, jako obiekt rozładowania emocji. Ważnym czynnikiem, może być tu też rola jaką przybiera dziecko w rodzinie.

W niniejszym badaniu większość osób wskazywała na ojca jako sprawce przemocy. Niekonsekwencja i nadmierne wymagania stawiane swoim dzieciom mogły przyczyniać się do stosowania przez niego przemocy względem potomstwa. Matki, często same będące ofiarami, postrzegane są przez swoje dzieci jako mało zaradne i niezdolne do sprzeciw stawienia się sprawcy.

Warto zauważyć, że struktura i funkcjonowanie rodziny z problemem alkoholowym są zwykle bardzo złożone, niejednorodne i niewydolne. Rodzinami tymi rządzą nieco inne mechanizmy i reguły niż rodzinami zdrowymi. Mogą one zatem w inny sposób wpływać na rozwój osób w niej wychowywanych. Dorosłe Dzieci Alkoholików różnią się między sobą także rolami jakie przyjęli w dzieciństwie, które warunkowały ich zachowanie i obowiązki. Ważne jest aby zauważyć, że różne osoby mogą odmiennie reagować na uzależnienie od alkoholu bliskich sobie osób. Niestety częściej doświadczają oni negatywnych 
wydarzeń w swoim życiu [22]. Grupa Dorosłych Dzieci Alkoholików wykazuje mniejszą odporność, poziom samooceny i wsparcia $\mathrm{w}$ porównaniu $\mathrm{z}$ grupą kontrolną. Zarówno wsparcie społeczne jak i poziom samooceny ma związek z poziomem odporności osób DDA. Istotne jest opracowanie programów podnoszących poziom poczucia własnej wartości u tych osób [23].

Dorosłe Dzieci Alkoholików niechętnie wracają pamięcią do wydarzeń $\mathrm{z}$ dzieciństwa oraz z dość dużym oporem rozmawiają o swoich rodzicach. Zazwyczaj odczuwają oni presję otoczenia, chcą uniknąć stygmatyzacji. Sytuacja ta może utrudnić tym osobom rozwiązywanie problemów w codziennym życiu [24].

Osoby badane w czasie dojrzewania i dorosłości mogły czerpać z wielu zasobów, których nie objęło badanie m.in. wsparcia dalszej rodziny, przyjaciół i środowiska szkolnego/zawodowego, obecnej sytuacji, psychoterapii nie związanej z byciem dorosłym dzieckiem alkoholika[25].

\section{Wnioski}

Wnioski płynące z powyższych badań skłaniają do refleksji nad rolą postaw rodzicielskich w kształtowaniu się nadziei podstawowej, samooceny i satysfakcji z życia w odniesieniu do dzieci, których rodzic lub oboje opiekunów są uzależnieniod alkoholu. Ważną wydaje się być, i to nie tylko $w$ rodzinach z problemem uzależnienia, potrzeba kształtowania $\mathrm{w}$ rodzicach pozytywnych postaw rodzicielskich, które wzmacniają zasoby rodziny i pozwalają wszystkim jej członkom rozwijać swój potencjał.Istotne jest poszukiwanie czynników, które mogą uchronić dzieci przed wpływem negatywnych postaw. Wskazana byłaby więc praca psychologiczna $\mathrm{z}$ rodzicami w zakresie psychoedukacji, technik radzenia sobie ze stresem, emocjami i kształtująca w nich umiejętności wychowawcze, pozwalające na kształtowanie określonych postaw u ich potomstwa. W przyszłych badaniach nad tym obszarem warto byłoby zwrócić uwagę na fakt, iż samoocena, satysfakcja z życia i nadzieja podstawowa mogą kształtować się i ulegać małym zmianom $\mathrm{w}$ trakcie całego życia osoby. Warto byłoby przeprowadzić badania długofalowe i skupić się na porównaniu osób przed i po terapii. Ze względu na rozległość i wielkowymiarowość problemu dorastania $\mathrm{w}$ rodzinie $\mathrm{z}$ problemem alkoholowym warto byłoby $\mathrm{w}$ przyszłych badaniach dodać do metod ilościowych tj. ankiet i kwestionariuszy także metody jakościowe np. pogłębiony wywiad.

\section{Conflict of interest}

The authors have declared no conflict of interest.

\section{References:}

1. Woronowicz BT. Bez tajemnic. 0 uzależnieniach i ich leczeniu. Warszawa; Instytut Psychiatrii i Neurologii: 2001.

2. Sztander W.Dzieci w rodzinie z problemem alkoholowym. Warszawa; PARPA.: 2003.

3. Ryś M.Role pełnione w rodzinie z problemem alkoholowym a poczucie własnej wartości i relacje interpersonalne z najbliższymi u Dorosłych Dzieci Alkoholików. Kwartalnik Naukowy Towarzystwa Uniwersyteckiego FIDESET RATIO 4 (8) 2011: 93-130.

4. Cierpiałkowska L. Rodzina a alkoholizm. Studium rozwojowosystemowe. Przegląd Psychologiczny. 1992; 1: 51-63.

5. Rembowski J. Rodzina $\mathrm{w}$ świetle psychologii. Warszawa;Wydawnictwa Szkolne i Pedagogiczne: 1978.

6. Tyszkowa M. Rozwój dziecka w rodzinie i poza rodziną. Poznań; Wydawnictwo Naukowe Uniwersytetu im. A. Mickiewicza: 1985.

7. Plopa M. Psychologia rodziny: teoria i badania. Elbląg; Wydawnictwo Elbląskiej Uczelni Humanistyczno-Ekonomicznej: 2005.

8. Timoszyk-Tomczak C, Bugajska B. Satysfakcja z życia a perspektywa przyszłościowa w starości. OpusculaSociologica, 2013;2(4): 83-95.

9. Zalewska A. Dwa światy: emocjonalne i poznawcze oceny jakości życia i ich uwarunkowania u osób o wysokiej i niskiej reaktywności. Warszawa; Wydawnictwo Szkoły Wyższej Psychologii Społecznej „Academica”: 2003.

10. Argyle M. Psychologia szczęścia. Wrocław; Wydawnictwo Astrum: 2004.

11. Niebrzydowski L. O poznawaniu i ocenie samego siebie. Warszawa; Nasza Księgarnia: 1976.

12. Carr A. Psychologia pozytywna. Nauka o szczęściu i ludzkich siłach. Poznań; Zysk i S-ka: 2009.

13. Erikson E. Dzieciństwo i społeczeństwo. Poznań; Rebis: 2000.

14. Trzebiński J, Zięba M. Nadzieja, strata, rozwój. Psychologia Jakości Życia. 2003; 1: 5-33.

15. Plopa M. Kwestionariusz retrospektywnej oceny postaw rodziców (KPR-Roc).Podręcznik. Wydawnictwo: Wizja Press \& IT, Warszawa. 2008.

16. Dzwonkowska I, Lachowicz-Tabaczek K, Łaguna, M. Samoocena i jej pomiar: Polska adaptacja skali SES M. Rosenberga. Podręcznik. Warszawa: Pracownia Testów Psychologicznych PTP. 2008.

17. Juczyński Z. Narzędzia pomiaru w promocji zdrowia, Pracownia Testów Psychologicznych PTP, Warszawa. 2001

18. Zięba M. Właściwości psychometryczne kwestionariusza BHI-R. Wstępny raport z badań walidacyjnych. URL:http://nadzieja podstawowa.pl/wp-content/uploads/2013 /05/Wlasciwoscipsychometryczne-kwestionariusza-BHI-R.-Wstepny-raport-zbadan-walidacyjnych.pdf

19. Ziemska M. Postawy rodzicielskie. Warszawa: Wiedza Powszechna: 1973.

20. Łaguna M, Lachowicz-Tabaczek K, Dzwonkowska I. Skala Samooceny SES Morrisa Rosenberga- polska adaptacja metody, Psychologia społeczna. 2007;2 (4): 164-176.

21. Krok D. Nadzieja jako predyktor wymiarów dobrostanu psychicznego. Polskie Forum Psychologiczne. 2013; 18(2): 157-172.

22. Drapkin ML, Eddie D, Buffington AJ, McCrady BS. Alcohol-Specific Coping Styles of Adult Children of Individuals with Alcohol Use Disorders and Associations with Psychosocial Functioning. Alcohol Alcohol. 2015; 50(4):463-9.

23. Kim HK, Lee MH. Factors influencing resilience of adult children of alcoholics among college students. J Korean AcadNurs. 2011; 41(5):642-51.

24. Haverfield MC, Theiss JA. Parent's alcoholism severity and family topic avoidance about alcohol as predictors of perceived stigma 
among adult children of alcoholics: Implications for emotional and psychological resilience.Health Commun. 2016;31(5):606-16.

25. Grzegorzewska I, CierpiałkowskaL. Pozytywna i negatywna adaptacja dzieci i młodzieży rodziców uzależnionych od alkoholu.Alcoholism and DrugAddiction. 2015; 28(4)221-233.

\section{Correspondence address}

Agnieszka Samochowiec,

email: agnieszkasamochowiec@gmail.com,

Department of Clinical Psychology and Psychoprophylaxis,

Institute of Psychology, University of Szczecin,

Krakowska 69, 71-017 Szczecin, Poland,

Tel / Fax : + 48-91-4443240

Otrzymano: 05.08.2017

Zrecenzowano:26.08.2017,29.09.2017,08.11.2017,05.12.2017

Przyjęto do druku: 11.12.2017 